\title{
Cytotoxic Property of Grias neuberthii Extract on Human Colon Cancer Cells: A Crucial Role of Autophagy
}

\author{
Luis M. Guamán-Ortiz $\mathbb{D}^{1},{ }^{1}$ Juan C. Romero-Benavides $\mathbb{D}^{2},{ }^{2}$ Alirica I. Suarez, ${ }^{2,3}$ \\ Stephania Torres-Aguilar, ${ }^{1}$ Paola Castillo-Veintimilla, ${ }^{2,4}$ Jimmy Samaniego-Romero, ${ }^{1}$ \\ Kevin Ortiz-Diaz, ${ }^{1}$ and Natalia Bailon-Moscoso $\mathbb{D}^{1}$ \\ ${ }^{1}$ Departamento de Ciencias de la Salud, Universidad Técnica Particular de Loja, Loja 1101608, Ecuador \\ ${ }^{2}$ Departamento de Química y Ciencias Exactas, Universidad Técnica Particular de Loja, Loja 1101608, Ecuador \\ ${ }^{3}$ Facultad de Farmacia, Universidad Central de Venezuela, Caracas 1050, Venezuela \\ ${ }^{4}$ Programa Nacional para el Abordaje Multidisciplinario de las Parasitosis Desatendidas en el Ecuador PROPAD, \\ Instituto Nacional de Investigaciones en Salud Pública LIP, Guayaquil 3961, Ecuador
}

Correspondence should be addressed to Natalia Bailon-Moscoso; ncbailon@utpl.edu.ec

Received 28 June 2019; Accepted 10 March 2020; Published 1 April 2020

Academic Editor: Monica Borgatti

Copyright ( 92020 Luis M. Guamán-Ortiz et al. This is an open access article distributed under the Creative Commons Attribution License, which permits unrestricted use, distribution, and reproduction in any medium, provided the original work is properly cited.

\begin{abstract}
Traditional herbal medicine has become an important alternative in the treatment of various cancer types, including colon cancer, which represents one of the main health problems around the world. Therefore, the search for new therapies to counteract this disease is very active. Grias neuberthii is an endemic plant located in the Ecuadorian Amazon region, which has been used in traditional medicine for its pharmacological properties, including its ability to inhibit tumor cell growth, although scientific studies are limited. We have analyzed the effect of this plant on two colon carcinoma cell lines, that is, RKO (normal p53) and SW613-B3 (mutated p53) cells. Among several extracts obtained from various parts of G. neuberthii plant, we identified the extract with the greatest cytotoxic potential, derived from the stem bark. The cytotoxic effect was similar on both cell lines, thus indicating that it is independent of the status of p53. However, significant differences were observed after the analysis of colony formation, with RKO cells being more sensitive than SW613-B3. No evidence for apoptotic markers was recorded; nevertheless, both cell lines showed signs of autophagy after the treatment, including increased Beclin-1 and LC3-II and decreased p62. Finally, three chemical compounds, possibly responsible for the effect observed in both cell lines, were identified: lupeol (1), $3^{\prime}$-O-methyl ellagic acid 4-O$\beta$-D-rhamnopyranoside (2), and 19- $\alpha$-hydroxy-asiatic acid monoglucoside (3).
\end{abstract}

\section{Introduction}

Colorectal cancer ranks third in terms of incidence, but second in terms of mortality. [1] Colorectal cancer is increasing in Central and South America due to an ongoing transition towards higher levels of human development. [2] Understanding the mechanisms underlying the effect of apoptotic/autophagic regulators should generate new ideas and opportunities for chemotherapeutic intervention and the potential treatment of cancer patients. [3].

Natural products continue to be an important source of leads for new medicines. Historically, natural products from plants and animals have been the source of virtually all medicinal preparations and, more recently, natural products have continued to enter clinical trials or to provide leads for compounds that have entered clinical trials. [4] The production of secondary metabolites is favored by the different microenvironments. Continental Ecuador is a region with the third-highest density of endemic plant species worldwide. It is shown in [5] that G. neuberthi (Lecythidaceae) is endemic to Colombia, Ecuador, and Peru. In accordance with the ethnomedical uses reported in various herbaria from Ecuador and bibliographical references, medicinal uses (including antitumor) described for G. neuberthii are related 
to the digestive system. [6, 7] The objective of this work was to study the effect of $G$. neuberthii extracts in human colon tumor cell lines as cytotoxic agents, understanding the mechanism responsible for inducing cell death, and determining the possible secondary metabolites involved. It is important to determine the type of cell death that natural products might be inducing and whether the activation of the p53 plays an important role in the cytotoxic effect. Thus, we have selected two colon cancer cell lines, one with normal p53 and another with mutated p53.

\section{Materials and Methods}

2.1. Plant Material. G. neuberthii was collected on a farm in Lumbaqui $\left(00^{\circ} 01^{\prime} 46^{\prime \prime}\right.$ Lat. S; $77^{\circ} 10^{\prime} 24^{\prime \prime}$ Long. O, 366 m.a.s.l) Sucumbios Province of Ecuador. A sample specimen (LOJA49) was deposited in the Herbarium of Universidad Nacional de Loja, Ecuador, and identified by Xavier Cornejo and Zhofre Aguirre.

2.2. Preparation Extract. The aerial parts (leaves, stem bark, fruit, and seed) were reduced to fine particles by grinding to a suitable size and then were dried at $30^{\circ} \mathrm{C}$ for seven days in dryer trays with air flow.

The dried and ground aerial parts of G. neuberthii $(4045 \mathrm{~g}$ ) were macerated at room temperature for $72 \mathrm{~h}$ in a light-free environment, with hexane, ethyl acetate, and methanol, sequentially, with $5 \mathrm{~L}$ of each solvent; the procedure was repeated three times. The extracts were filtered using filter paper; all extracts were concentrated at $50 \mathrm{mbar}$ and $37^{\circ} \mathrm{C}$ on a rotary evaporator (Buchi R210, Switzerland), and subsequently stored at $4^{\circ} \mathrm{C}$ and protected from light until further use.

Thin-layer chromatography using aluminum plates coated with silica gel 60 F254 (Merck, Germany) was performed on each extract.

For biological studies, stock solutions $(40 \mathrm{mg} / \mathrm{mL})$ were prepared in dimethylsulfoxide (DMSO-Sigma Aldrich, USA) and stored at $-20^{\circ} \mathrm{C}$ until use. The aliquots were diluted to obtain the appropriate concentrations before use.

2.3. Phytochemical Screening. Phytochemical screening to test for the presence of secondary metabolites (alkaloids, terpenoids, steroids, flavonoids, tannins, saponins, and quinones) and proteins, carbohydrates, and fats and oils in the extracts was carried out using standard procedures [8].

2.4. Characterization and Identification of Secondary Metabolites. Melting points were determined using a Fisher-Johns apparatus. The ${ }^{1} \mathrm{H}$ and ${ }^{13} \mathrm{C}$ NMR spectra were recorded at $400 \mathrm{MHz}$ and $100 \mathrm{MHz}$, respectively, on Varian $400 \mathrm{MHz}$ Premium Shielded Equipment (Varian, USA) using tetramethylsilane as an internal reference. $\mathrm{CDCl}_{3}$, $\mathrm{C}_{5} \mathrm{D}_{5} \mathrm{~N}$, and DMSO- $\mathrm{d}_{6}$ were used as solvents; chemical shifts were expressed in parts per million (ppm), and coupling constants $(J)$ were reported in $\mathrm{Hz}$.
2.5. Extraction and Isolation of Compounds. The most active extract, methanol extract of stem bark (GNSbM), was partitioned, and $30 \mathrm{~g}$ was dissolved in $\mathrm{MeOH}: \mathrm{H}_{2} \mathrm{O}(9: 1)$ in a ratio of $1: 20$ (extract: solvent) $(540 \mathrm{~mL}$ of $\mathrm{MeOH}$ and $60 \mathrm{~mL}$ of $\mathrm{H}_{2} \mathrm{O}$ ) and sequentially partitioned three times with $400 \mathrm{~mL}$ of each solvent hexane (Hex), dichloromethane (DCM), and ethyl acetate (EtOAc) using a separatory funnel at room temperature. The solvents were removed using a rotary evaporator (Buchi R210; Switzerland, Flawil) at $35^{\circ} \mathrm{C}$ under vacuum. From the hexane fraction (GNSbM-F-Hex), $0.1330 \mathrm{~g}$ was obtained. The dichloromethane fraction (GNSbM-F-DCM) yielded $2.3697 \mathrm{~g}$, the ethyl acetate fraction (GNSbM-F-EtOAc) yielded $10.5817 \mathrm{~g}$, and the aqueous fraction (GNSbM-FAq) yielded $16.8156 \mathrm{~g}$.

The hexane fraction (GNSbM-F-Hex) was submitted to column chromatography, with an extract/silica ratio of 1 : 200. The column was eluted according to a gradient of increasing polarity, from DCM : $\mathrm{MeOH}: \mathrm{H}_{2} \mathrm{O}(67: 28: 5)$ to DCM : MeOH: $\mathrm{H}_{2} \mathrm{O}(55: 40: 5)$, obtaining a total of 12 fractions of GNSbF-Hex (GNSbF-Hex-1-12). The GNSbFHex-3 fraction was purified by column chromatography, with an isocratic system of Hex:EtOAc $(90: 10)$ to get compound 1. The spectral properties of this compound, including ${ }^{1} \mathrm{H}-\mathrm{NMR}$ and ${ }^{13} \mathrm{C}-\mathrm{NMR}$ data, were identical to those previously described in the literature for the lupeol. [9].

Lupeol (1) $\mathrm{C}_{30} \mathrm{H}_{50} \mathrm{O}$ crystals, m.p. $215-216^{\circ} \mathrm{C} .{ }^{1} \mathrm{H}-\mathrm{NMR}$ $\left(\mathrm{CDCl}_{3}, 400 \mathrm{MHz}\right): \delta$ (ppm); 4.68, $4.56(2 \mathrm{H}, \mathrm{s}, \mathrm{H}-29 \mathrm{a}, 29 \mathrm{~b})$, $3.18(1 \mathrm{H}, \mathrm{dd}, J=4.76 \mathrm{~Hz}, 11.2 \mathrm{~Hz}, \mathrm{H}-3), 1.25,1.02,0.96,0.94$, 0.82, 0.78, 0.75, (each $\left.3 \mathrm{H}, \mathrm{s}, \mathrm{CH}_{3} \times 7\right) .{ }^{13} \mathrm{C}-\mathrm{NMR}\left(\mathrm{CDCl}_{3}\right.$, $100 \mathrm{MHz}) ; \delta$ (ppm); 38.2 (C-1), 25.3 (C-2), 79.2 (C-3), 38.7 (C-4), 55.4 (C-5), 18.5 (C-6), 34.4 (C-7), 40.9 (C-8), 50.6 (C9), 37.3 (C-10), 21.1 (C-11), 27.6 (C-12), 39.0 (C-13), 42.9 (C14) 27.6 (C-15), 35.7 (C-16), 42.9 (C-17), 48.5 (C-18), 48.1 (C-19), 151.1 (C-20), 29.9 (C-21), 40.2 (C-22), 28.1 (C-23), 15.5(C-24), 16.3 (C-25), 16.2 (C-26), 14.7 (C-27), 18.5 (C28), 109.5 (C-29), 19.5 (C-30).

The ethyl acetate fraction (GNSbM-F-EtOAc) was purified by column chromatography, with an extract/silica ratio of $1: 200$. The column was eluted with $\mathrm{DCM}: \mathrm{MeOH}$ : $\mathrm{H}_{2} \mathrm{O}$ 85:25:4 obtaining a total of 11 fractions GNSbMFEtOAc (GNSbMF-EtOAc-1-11). The fraction GNSbMFEtOAc-2 was also purified by column chromatography, with an isocratic system of EtOAc-MeOH 90:10 to get compound 2 , identified as $3^{\prime}$-O-methyl ellagic acid $4-\mathrm{O}-\beta-\mathrm{D}$ rhamnopyranoside.

3 '-O-Methyl ellagic acid 4-O- $\beta$-D-rhamnopyranoside (2) $\mathrm{C}_{21} \mathrm{H}_{18} \mathrm{O}_{12}$, white amorphous powder, m.p. $248-250^{\circ} \mathrm{C}$. ${ }^{1} \mathrm{H}-\mathrm{NMR}\left(\mathrm{C}_{5} \mathrm{D}_{5} \mathrm{~N}, 400 \mathrm{MHz}\right): \delta(\mathrm{ppm}) 8.58(1 \mathrm{H}, \mathrm{s}, \mathrm{H}-5), 8.14$ $\left(1 \mathrm{H}, \mathrm{s}, \mathrm{H}-5^{\prime}\right), 6.53\left(1 \mathrm{H}, \mathrm{d}, J=1.5 \mathrm{~Hz}, \mathrm{H}-1^{\prime \prime}\right), 4.98(1 \mathrm{H}, \mathrm{br}$, $\left.\mathrm{H}-2^{\prime \prime}\right), 4.88\left(1 \mathrm{H}, \mathrm{d}, J=3.4 \mathrm{~Hz}, \mathrm{H}-3^{\prime \prime}\right), 4.85(1 \mathrm{H}, \mathrm{d}, J=3.4 \mathrm{~Hz}$, $\left.\mathrm{H}-5^{\prime \prime}\right), 4.51\left(1 \mathrm{H}, \mathrm{t}, J=9.4 \mathrm{~Hz}, \mathrm{H}-4^{\prime \prime}\right), 4.28\left(3 \mathrm{H}, \mathrm{s}, 3^{\prime}-\mathrm{OCH}_{3}\right)$, $1.76\left(3 \mathrm{H}, \mathrm{d}, J=6.2 \mathrm{~Hz}, \mathrm{CH}_{3}-6^{\prime \prime}\right) ;{ }^{13} \mathrm{C} \mathrm{NMR}:\left(\mathrm{C}_{5} \mathrm{D}_{5} \mathrm{~N}\right.$, $100 \mathrm{MHz}) \delta$ (ppm): $113.3(\mathrm{C}-1), 113.3\left(\mathrm{C}-1^{\prime}\right), 135.9(\mathrm{C}-2)$, $143.2\left(\mathrm{C}-2^{\prime}\right), 142.7(\mathrm{C}-3), 139.5\left(\mathrm{C}-3^{\prime}\right), 146.7(\mathrm{C}-4), 152.8(\mathrm{C}-$ $\left.4^{\prime}\right), 111.3(\mathrm{C}-5), 110.7\left(\mathrm{C}-5^{\prime}\right), 114.3(\mathrm{C}-6), 113.4\left(\mathrm{C}-6^{\prime}\right), 158.8$ (C-7), $158.0\left(\mathrm{C}-7^{\prime}\right), 100.7\left(\mathrm{C}-1^{\prime \prime}\right), 70.0\left(\mathrm{C}-2^{\prime \prime}\right), 71.1\left(\mathrm{C}-3^{\prime \prime}\right)$, $72.8\left(\mathrm{C}-4^{\prime \prime}\right), 70.4\left(\mathrm{C}-5^{\prime \prime}\right), 17.2\left(\mathrm{C}-6^{\prime \prime}\right), 59.8$ (3'-OMe). 
The fraction GNSbMF-EtOAc-3 was purified by column chromatography, with an isocratic system of EtOAc: $\mathrm{MeOH}$ $85: 15$, to get compound 3, identified as $19-\alpha$-hydroxy-asiatic acid monoglucoside.

19- $\alpha$-Hydroxy-asiatic acid monoglucoside (3) $\mathrm{C}_{36} \mathrm{H}_{58} \mathrm{O}_{11}$, white amorphous powder, m.p. $220-221^{\circ} \mathrm{C} .{ }^{1} \mathrm{H}-$ NMR (DMSO-d6, $100 \mathrm{MHz}): \delta(\mathrm{ppm}) ; 5.23(1 \mathrm{H}, \mathrm{d}$, $\left.J=7.9 \mathrm{~Hz}, \mathrm{H}-1^{\prime}\right), 4.29(1 \mathrm{H}, \mathrm{s}, \mathrm{H}-2), \delta ; 4.15\left(1 \mathrm{H}, \mathrm{m}, \mathrm{H}-5^{\prime}\right)$; 4.28-4.57 (5H, m, H-2' $\left., \mathrm{H}-3^{\prime}, \mathrm{H}-4^{\prime}, \mathrm{H}^{\prime} 6^{\prime}\right), 3.82(1 \mathrm{H}, \mathrm{d}$, $J=9.3 \mathrm{~Hz}, \mathrm{H}-3), 5.23(1 \mathrm{H}, \mathrm{m}, \mathrm{H}-12) 3.12(1 \mathrm{H}, \mathrm{d}, J=14.3 \mathrm{~Hz}$, $\mathrm{H}-18), 1.27,1.08,0.94,0.65,0.53$ (each $\left.3 \mathrm{H}, \mathrm{s}, \mathrm{CH}_{3} \times 5\right) ;{ }^{13} \mathrm{C}-$ NMR (DMSO-d6, $100 \mathrm{MHz}) ; \delta(\mathrm{ppm}) ; 47.5$ (C-1), 67.7 (C2), 78.2 (C-3), 42.7 (C-4), 47.1 (C-5), 17.7 (C-6), 34.9 (C-7), 41.4 (C-8), 46.8 (C-9), 37.4 (C-10), 16.8 (C-11), 127.2 (C-12), 138.4 (C-13), 41.3 (C-14) 28.8 (C-15), 24.4 (C-16), 46.8 (C17), 53.4 (C-18), 72.4 (C-19), 41.3 (C-20), 32.2 (C-21), 36.9 (C-22), 67.7 (C-23), 13.7 (C-24), 16.9 (C-25), 16.8 (C-26), 23.5 (C-27), 175.8 (C-28), 16.6 (C-29), 16.4 (C-30), 94.2 (C$\left.1^{\prime}\right), 74.2\left(\mathrm{C}-2^{\prime}\right), 76.8\left(\mathrm{C}-3^{\prime}\right), 71.8\left(\mathrm{C}-4^{\prime}\right), 75.8\left(\mathrm{C}-5^{\prime}\right), 69.7(\mathrm{C}-$ $\left.6^{\prime}\right)$.

2.6. Cell Culture and Treatments. Two human colon carcinoma cell lines were used to analyze the antiproliferative effect of the G. neuberthii extracts: RKO and SW613-B3. Cells were grown at $37^{\circ} \mathrm{C}$ and $5 \% \mathrm{CO}_{2}$ atmosphere, in RPMI medium supplemented with 10\% FBS (Sigma Aldrich, USA), $0.1 \mathrm{mg} / \mathrm{mL}$ penicillin, $100 \mathrm{UI} / \mathrm{mL}$ streptomycin, and $2 \mathrm{mM} \mathrm{L}$ glutamine (all reagents were from Gibco-Thermo Fisher Scientific, USA). Twenty-four hours after seeding, cells were treated for $48 \mathrm{~h}$ with the G. neuberthii extracts at $50 \mu \mathrm{g} / \mathrm{mL}$ or increasing doses or $0.3 \mu \mathrm{g} / \mathrm{mL}$ Doxorubicin (Dxo-Sigma Aldrich, USA; stock solution: $2 \mathrm{mg} / \mathrm{mL}$ in water). Final concentration of DMSO, $<0.2 \%(\mathrm{v} / \mathrm{v})$, in the culture medium did not alter the tested activities.

2.7. Viability Assay. Different G. neuberthii extracts were evaluated on cell proliferation by the MTS metabolic viability assay, according to Guamán-Ortiz et al. (2015). [10] Briefly, $2 \times 10^{3}$ cells were seeded in 96 -well plates in $100 \mu \mathrm{L}$ of medium per well and incubated for $24 \mathrm{~h}$. Then, cells were treated in triplicate for $48 \mathrm{~h}$ either with $50 \mu \mathrm{g} / \mathrm{mL}$ of each extract or $0.3 \mu \mathrm{g} / \mathrm{mL}$ Dxo. Four hours before finishing the treatment, $20 \mu \mathrm{L}$ of Cell Titer 96 Aqueous One Solution cell proliferation reagent (Promega, USA) was added to each well. The plates were then maintained for $4 \mathrm{~h}$ at $37^{\circ} \mathrm{C}$; the absorbance of each sample was measured with a microplate reader (Megallan, Tecan, Switzerland) at a wavelength of $492 \mathrm{~nm}$. Absorbance from control was used as reference values $(100 \%$ of viability) to normalize the data of treated samples. In order to calculate the $\mathrm{IC}_{50}$, the most active extracts were selected and exposed to the cells for $48 \mathrm{~h}$ with increasing concentrations $(5-50 \mu \mathrm{g} / \mathrm{mL})$ and processed as above.

2.8. Morphological Analysis. Both cell lines were exposed to the most active extract of G. neubertii (GNSbM) in order to observe the induced effect. In brief, $5 \times 10^{4}$ cells $/ \mathrm{mL}$ were seeded in $3.5-\mathrm{cm}$ diameter Petri dishes and incubated for $24 \mathrm{~h}$. Next, cells were exposed to the extract for $48 \mathrm{~h}$ with their representative $\mathrm{IC}_{50}$ calculated. Cells were then observed using a light microscope (Axioskop 2 plus-Zeiss, Germany) equipped with a $40 \mathrm{x}$ objective. Images were acquired with a digital camera Basler scA1300-32 fm using its software.

2.9. Cell Cycle Analysis. Cell cycle distribution was evaluated using propidium iodide (PI, P4170, Sigma Aldrich, USA) staining processed according to the previous protocol, Bailon-Moscoso et al. [11]. In summary, cells were seeded in 6-well plates at a density of $1 \times 10^{6}$ cells in $2 \mathrm{~mL}$ of medium per well and incubated for $24 \mathrm{~h}$. Cells were then treated for $48 \mathrm{~h}$ with 20,30 , and $50 \mu \mathrm{g} / \mathrm{mL}$ of GNSbM extract or $0.3 \mu \mathrm{g} /$ $\mathrm{mL}$ Dxo. Detached and attached cells were harvested and washed with PBS. Cell pellets were obtained and resuspended in $100 \mu \mathrm{L}$ of PBS, fixed with absolute ethanol, and maintained at $-20^{\circ} \mathrm{C}$ for $24 \mathrm{~h}$. Cells were washed with PBS and incubated in the dark for $30 \mathrm{~min}$ at room temperature in the staining buffer $(50 \mu \mathrm{g} / \mathrm{mL}$ PI, $0.1 \%$ sodium citrate, $0.1 \%$ Triton-X-100, and $100 \mu \mathrm{g} / \mathrm{mL}$ RNase A). Cells in the $G_{1}, \mathrm{~S}$, and $G_{2} / \mathrm{M}$-phase were subsequently analyzed using a FACSCanto II flow cytometer (Becton Dickinson, USA). Acquired data were analyzed using DIVA and ModFit LT software (Becton Dickinson).

2.10. Cloning Assay. To evaluate the clonogenic capacity, $2.5 \times 10^{2}$ cells were seeded in duplicate in $6 \mathrm{~cm}$ diameter Petri dishes in $2 \mathrm{~mL}$ of medium and incubated for $24 \mathrm{~h}$. Cells were then treated for $48 \mathrm{~h}$ with 20,30 , and $50 \mu \mathrm{g} / \mathrm{mL}$ of GNSbM extract or $0.3 \mu \mathrm{g} / \mathrm{mL}$ Dxo, washed with BPS, incubated with $2 \mathrm{~mL}$ of complete medium for 7 days, and then processed according to Guamán-Ortiz et al. [12]. Colony-forming ability data were expressed as a percentage relative to control.

2.11. Western Blot Analysis. To determine the induced cell death pathway, 20,30 , and $50 \mu \mathrm{g} / \mathrm{mL}$ of GNSbM extract were exposed on both cell lines for $48 \mathrm{~h}$. Additionally, as positive controls: cells were exposed for $10 \mathrm{~min}$ to UV radiation (Osram, G30T8, 30W Germicidal UV-C Lamp, $254 \mathrm{~nm}$ ) for apoptosis induction [13] or for $1 \mathrm{~h}$ to PBS for starvationinduced autophagy [14], before being harvested. Apoptotic and autophagic proteins were analyzed through Western Blot analysis. The methodology was applied according to Bailon-Moscoso et al. [15]. Briefly, separated proteins from a SDS-PAGE were transferred to a PVDF membrane (IPVH00010, Immobilon-P, $0.45 \mu \mathrm{m}$, EMD/Millipore, Billerica, Boston, MA, USA) and incubated with primary antibodies: p53 (sc-81168), Beclin-1 (sc-48341), SQSTM 1/p62 (sc-48402) (Santa Cruz Biotechnology, USA), PARP (\#9542), Bax (\#2774), Bcl-2 (\#15071) LC3A/B (\#12741), and $\beta$-Tubulin (\#2128) (Cell Signaling Technology, USA), as indicated by the manufacturer for immunoblotting. Secondary antibodies, anti-mouse IgG, HRP-linked (\#7076, Cell Signaling Technology, USA), and anti-rabbit IgG, HRPlinked (\#7074, Cell Signaling Technology, USA), were 
subsequently used. Immunoreactive bands were visualized using an enhanced chemiluminescence Luminata ${ }^{\mathrm{TM}}$ Crescendo Western HRP Substrate or Luminata ${ }^{\mathrm{TM}}$ Forte Western HRP Substrate (Millipore-Merck, Germany).

2.12. Statistical Analysis. Statistical analyses were carried out in GraphPad Prism 4 (GraphPad Software, USA). All data were reported as the means \pm SEM of three independently performed experiments, as detailed in each figure. The statistical significance was obtained with one-way analysis of variance (ANOVA) followed by the Dunnett posttest. A $P<0.05$ was considered to be statistically significant comparing the control to the samples.

\section{Results and Discussion}

3.1. Preliminary Phytochemical Study of Extracts. The phytochemical screening tests on extracts revealed the presence or absence of the main secondary metabolites and other phytochemicals based on the presence or absence of expected color changes (Table 1). The G. neuberthii fruit extracts in methanol (GNFM) are richer in secondary metabolites; the methanolic extracts of stem bark (GNSbM) contained alkaloids, flavonoids, tannins, quinones, and saponins. The highest percentage of yield was obtained from the methanol fraction of leaves GNLM (22.97\%), followed by that of hexane fraction of fruit GNFH (19.6\%), and methanol fraction of stem bark GNSbM (9.4\%). The lowest percentage of yield was obtained from the hexane fraction of seed GNSH $(0.17 \%)$. There was also variation in the physical appearance of the extracts (Supplementary Material, S1).

3.2. Cytotoxic Effect on Human Tumor Cell Lines. In order to analyze the antiproliferative effect of G. neuberthi on colon cancer cells, all the extracts obtained were then evaluated. Table 2 describes the viability percentages using $50 \mu \mathrm{g} / \mathrm{mL}$ of the different G. neuberthii extracts or Dxo $0.3 \mu \mathrm{g} / \mathrm{mL}$ on the human tumor cell lines after $48 \mathrm{~h}$ of treatment. Doxorubicin, an anthracycline antibiotic, has proved to induce cytotoxicity, cell cycle arrest, and apoptosis in a wide variety of tumor cell lines, including colon cancer cells; however, its clinical use is limited due its cardiotoxicity effect [16-18]. Cell growth viability was measured using the MTS assay, considering the control as $100 \%$ of viability. As expected, the SW613-B3 cell line (with p53 mutated) was more resistant to the treatment, in contrast to the RKO cell line. The extract GNSbM, whose extracting method was by maceration in methanol, demonstrated to be the most cytotoxic, with values under $20 \%$ of viability on both wt p53 RKO and SW613-B3 with mutated p53.

According to these results, the $\mathrm{IC}_{50}$ was calculated from the GNSbM extract (Figure 1(a)), which was 28 and $31.8 \mu \mathrm{g} /$ $\mathrm{mL}$ in SW613-B3 and RKO, respectively. As observed, after exposing to the $\mathrm{IC}_{50}$ of $\mathrm{GNSbM}$, that is approximately the same, both cell lines decrease in cell population, suggesting therefore that the effect observed is not dependent on p53 status.
The marked difference between these cell lines reveals that the SW613-B3 cells have the potential for recovery after treatment because of the results observed in colony-forming ability assay, where the cells were exposed to three different doses of GNSbM, 20, 30, and $50 \mu \mathrm{g} / \mathrm{mL}$. As observed in Figure 1(b), colony-forming ability decreases in a dosedependent manner in both cell lines; however, the SW613B3 cell line was less affected after $20 \mu \mathrm{g} / \mathrm{mL}(90 \%)$ and $\mathrm{IC}_{50}$ $(80 \%)$, in contrast to the RKO cell line, which was more sensitive $(60 \%)$. To note, SW613-B3 cell line has demonstrated to be resistant to different treatments. [12] Nevertheless, colony-forming ability decreases dramatically in both cell lines at the higher concentration $(50 \mu \mathrm{g} / \mathrm{mL})$. On the other hand, p53 has a well-known role in cell cycle progression, which after transactivation induces cell cycle arrest $[19,20]$; however, the statistical analysis of cell cycle distribution revealed that no significant cell cycle changes were occurring after the treatment of both wt and mutated p53 cell lines, as observed in those treated with Dxo (Figure 1(c)).

3.3. No Apoptosis Was Detected after Treatment with GNSbM. To further explore the type of cell death induced by the plant extract, both apoptosis and autophagy pathways were analyzed by Western blotting. It is also well known that p53 is involved in multiple cell death pathways, such as apoptosis and autophagy. [21, 22] In the apoptotic pathway, p53 is upregulated to transactivate and phosphorylate the Bax protein, thereby inducing the activation of the intrinsic apoptosis; at the same time $\mathrm{Bcl}-2$, an antiapoptotic protein, is downregulated in the presence of p53. [22] As observed in Figures 2(a) and 2(b), no overexpression of Bax protein was detected in the RKO cell line, despite the overexpression of p53 in a dose-dependent manner; furthermore, an increase of Bcl-2 expression was detected in the Western blot assay (Figure 2(b)), although this did not reach statistical significance relative to the control (Figure 2(a)).

Additionally, in the SW613-B3 cell line, the upregulation of p53 was not observed in any of the GNSbM doses used as expected (Figures 3(a) and 3(b)). In both cell lines, no proteolysis of PARP-1 protein, an apoptotic marker [23, 24], was detected after the GNSbM treatments (Figures 2 and 3), in contrast with the cleavage visible in cells exposed to UV radiation. [25].

3.4. GNSbM Extract Induces Autophagy. Autophagy pathway is activated after starvation conditions [26, 27], which induces the formation of autophagic vesicles or vacuoles called autophagosomes at the level of the cytoplasm. Therefore, the presence of vacuoles in both cell lines, observed in morphological analysis (Figure 1(a)), suggested the possible activation of the autophagic pathway $[12,28]$; thus, biomarkers for autophagy were evaluated. In this pathway, Bcl-2 is associated with Beclin-1. Once Beclin-1 is released, the autophagic pathway is activated [29]; LC3-I is converted into its active form LC3-II to induce the phagophore formation in the nucleation phase to enclose the obsolete proteins and organelles, tagged with p62, for degradation [30-33]. Forced autophagy could generate severe damage 
TABLE 1: Phytochemical constituents of extract from the aerial parts of G. neuberthi.

\begin{tabular}{|c|c|c|c|c|c|c|c|c|c|c|c|c|}
\hline \multirow[b]{2}{*}{ Test } & \multicolumn{3}{|c|}{ Fruit } & \multicolumn{3}{|c|}{ Seed } & \multicolumn{3}{|c|}{ Stem bark } & \multicolumn{3}{|c|}{ Leaves } \\
\hline & $\begin{array}{c}\text { Hex } \\
\text { GNFH }\end{array}$ & $\begin{array}{l}\text { EtOAc } \\
\text { GNFEa }\end{array}$ & $\begin{array}{l}\mathrm{MeOH} \\
\text { GNFM }\end{array}$ & $\begin{array}{c}\text { Hex } \\
\text { GNSH }\end{array}$ & $\begin{array}{l}\text { EtOAc } \\
\text { GNSEa }\end{array}$ & $\begin{array}{c}\mathrm{MeOH} \\
\mathrm{GNSH}\end{array}$ & $\begin{array}{c}\text { Hex } \\
\text { GNSbH }\end{array}$ & $\begin{array}{c}\text { EtOAc } \\
\text { GNSbEa }\end{array}$ & $\begin{array}{c}\mathrm{MeOH} \\
\text { GNSbM }\end{array}$ & $\begin{array}{c}\text { Hex } \\
\text { GNLH }\end{array}$ & $\begin{array}{l}\text { EtOAc } \\
\text { GNLEa }\end{array}$ & $\begin{array}{l}\mathrm{MeOH} \\
\text { GNLM }\end{array}$ \\
\hline Proteins & - & - & + & - & + & - & - & - & - & - & - & - \\
\hline Carbohydrates & - & - & + & - & - & - & - & - & - & - & - & + \\
\hline Fats & +++ & ++ & + & ++ & - & ++ & ++ & + & - & + & - & - \\
\hline Alkaloids & ++ & ++ & ++ & - & - & - & - & + & + & ++ & - & + \\
\hline $\begin{array}{l}\text { Terpenoids, } \\
\text { steroids }\end{array}$ & - & - & + & - & - & - & - & - & - & - & - & - \\
\hline Flavonoids & + & + & + & - & + & - & - & - & + & + & + & + \\
\hline Saponnins & - & - & + & - & - & - & - & + & +++ & - & - & + \\
\hline Quinones & - & - & ++ & - & - & - & - & - & ++ & - & - & ++ \\
\hline Tannins & - & - & + & + & - & + & - & + & + & - & + & + \\
\hline
\end{tabular}

$\mathrm{Hex}=$ hexane extract, $\mathrm{EtOAc}=$ ethyl acetate extract, $\mathrm{MeOH}=$ methanol extract, $+++=$ very strong positive, $++=$ strong positive, $+=$ fair positive, $-=$ absent.

Table 2: Cell Growth Viability: Cell lines were treated for $48 \mathrm{~h}$ with $50 \mu \mathrm{g} / \mathrm{mL}$ of G. neuberthii extract.

\begin{tabular}{|c|c|c|c|}
\hline Part of the plant & Extract & RKO & SW613-B3 \\
\hline Fruit & $\begin{array}{c}\text { GNFH } \\
\text { GNFEa } \\
\text { GNFM }\end{array}$ & $\begin{array}{c}96 \pm 6.79 \\
\text { NE } \\
72.2 \pm 6.38\end{array}$ & $\begin{array}{l}\mathrm{NE} \\
\mathrm{NE} \\
\mathrm{NE}\end{array}$ \\
\hline Seed & $\begin{array}{l}\text { GNSEa } \\
\text { GNSM }\end{array}$ & $\begin{array}{l}81.0 \pm 7.78 \\
74.7 \pm 4.36\end{array}$ & $\begin{array}{c}\mathrm{NE} \\
95.0 \pm 5.31\end{array}$ \\
\hline Stem bark & $\begin{array}{l}\text { GNSbEa } \\
\text { GNSbM }\end{array}$ & $\begin{array}{c}\mathrm{NE} \\
15.3 \pm 3.61\end{array}$ & $\begin{array}{c}\mathrm{NE} \\
10.4 \pm 2.24\end{array}$ \\
\hline Leaves & GNLM & $91.5 \pm 4.95$ & $\mathrm{NE}$ \\
\hline Control & $0.3 \mu \mathrm{g} / \mathrm{mL}$ Dxo & $10.8 \pm 4.02$ & $48.2 \pm 5.62$ \\
\hline
\end{tabular}

Control was considered as $100 \%$ of cell viability; three independent experiments in triplicate were performed. NE $=$ no effect.

that ends in the death of the cell [27]. In Figures 2(b) and 3(b), an upregulation of Beclin-1 was observed in both cell lines in a dose-dependent manner, although these results did not reach statistical significance. Dissociation between Bcl-2 and Beclin-1 is necessary for the initiation of autophagy; therefore, the increase of $\mathrm{Bcl}-2$ observed in the RKO cell line (Figure 2(b)) could be explained by this dissociation. Likewise, an increase in LC-3II was detected in both the RKO and SW613-B3 cell lines in a dose-dependent manner. The final step in autophagy is the degradation of charges in which p62 is involved (being also degraded). [32] As observed in both cell lines, p62 results in a decrease (Figures 2(a) and 3(a)), therefore elucidating the termination of the autophagic process and cell death pathway. Remarkably, it is possible that autophagy is playing a double role in the SW613-B3 cell line. It is well known that the autophagy mechanism is also active in tumor cell lines and has a role in survival $[22,34]$; as observed in the clonogenic assay, the SW613-B3 cell line is able to recover after treatment at the $\mathrm{IC}_{50}$ dose (Figure 1(b)).

3.5. Isolation and Identification of Secondary Metabolites Isolated from GNSbM. Phytochemical investigation of methanolic extract from the stem bark of G. neuberthii (GNSbM) led to the isolation and identification of three compounds identified as: lupeol (1), $3^{\prime}$-O-methyl ellagic acid 4-O- $\beta$-D-rhamnopyranoside (2), and 19- $\alpha$-hydroxy-asiatic acid monoglucoside (3), whose structures are shown in Figure 4. The spectral properties of these known compounds, including the ${ }^{1} \mathrm{H} N M R$ and ${ }^{13} \mathrm{C}$ NMR data, were identical to those previously described in the literature [9].

Compound 1 was crystals. Its ${ }^{1} \mathrm{H}$ NMR spectra in $\mathrm{CDCl}_{3}$ showed six singlets, corresponding to tertiary methyl groups, between 0.75 and $1.02 \mathrm{ppm}$ and a singlet at $1.25 \mathrm{ppm}$, typical of a methyl group in an isopropenyl system. Two olefinic protons at 4.68 and $4.56 \mathrm{ppm}$ are consistent with the methylene group of the same propylenic system. The ${ }^{13} \mathrm{C}$ NMR data showed the characteristic signals of C-3 at $79.2 \mathrm{ppm}, \mathrm{C}-20$ at $151.1 \mathrm{ppm}$, and C-29 at $109.5 \mathrm{ppm}$. [9] Compound 2 was a white amorphous powder. Its ${ }^{1} \mathrm{H}$ NMR spectra in deuterated pyridine showed two singlet signals at $\delta 8.58$ and 8.14 . A broad signal at $5.31 \mathrm{ppm}$ suggested a structure with some hydroxyls groups, which was corroborated with the few multiplets signals typical for carbohydrate moieties between 4.53 and $5.04 \mathrm{ppm}$. Among these signals, one singlet at $\delta 4.28$ integrating for $3 \mathrm{H}$ suggested a methoxy group in this compound. The broad band carbon NMR spectra showed 21 signals including 11 quaternary carbons indicating a very conjugated aromatic structure. From these signals, two were assigned to $\alpha, \beta$-unsaturated lactone carbonyls carbons at 158.0 and $158.2 \mathrm{ppm}$. The 


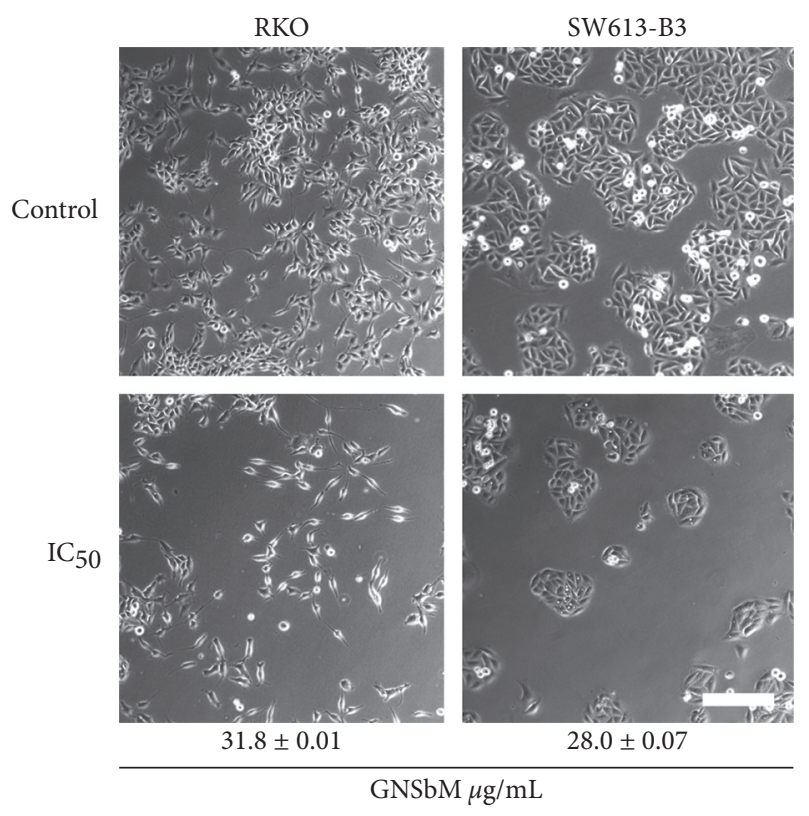

(a)

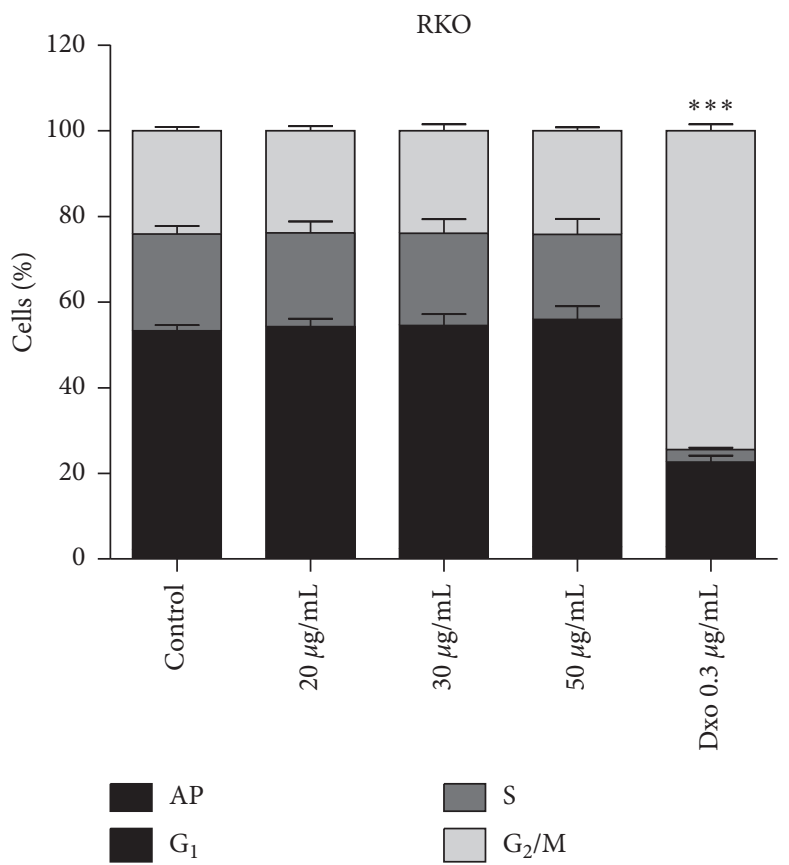

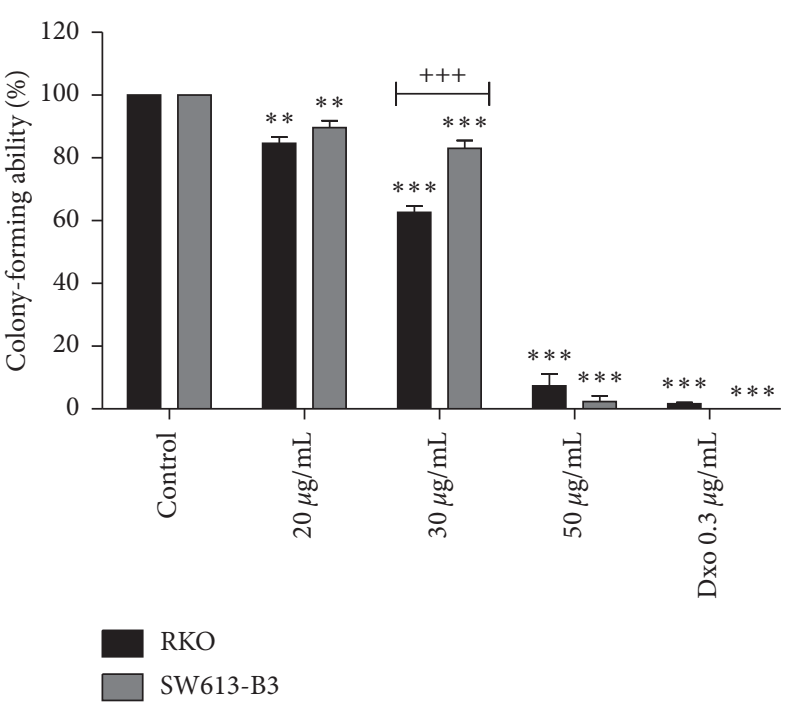

(b)

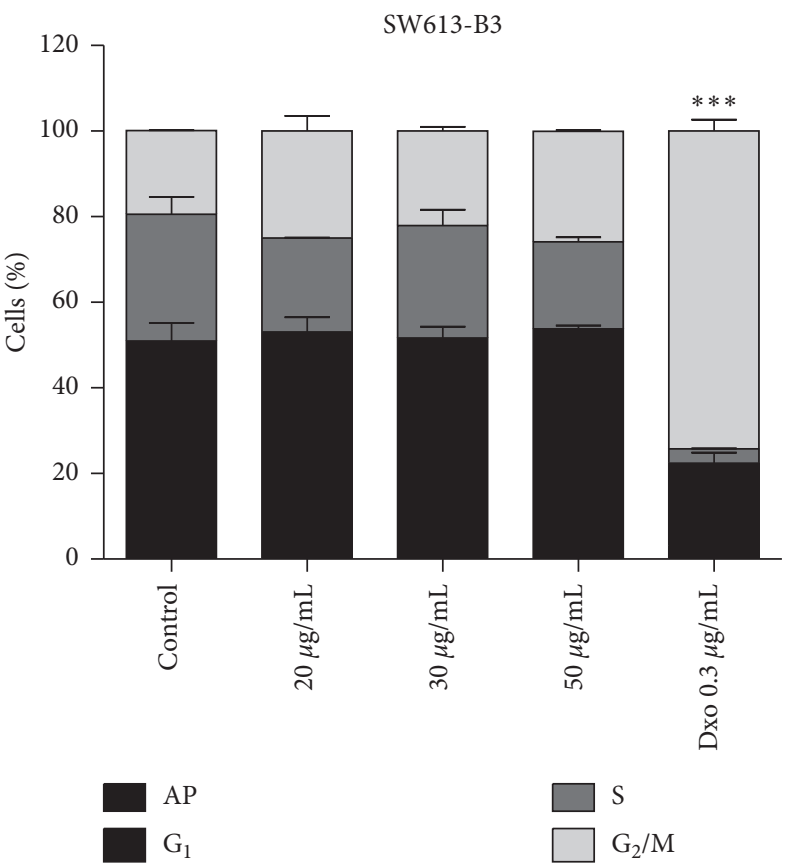

(c)

FiguRE 1: GNSbM extract demonstrated to be cytotoxic on RKO and SW613-B3 cell lines. (a) Morphological changes induced after $48 \mathrm{~h}$ of exposure at $\mathrm{IC}_{50}$ doses of the extract. Scale bar: $50 \mu \mathrm{m}$. (b) Cells were exposed to the extract for $48 \mathrm{~h}$ and formed colonies were counted based on clonogenic survival assay seven days after the treatment. The number of counted colonies was expressed as a percentage relative to control (defined as $100 \%)$. Data represented the mean $\pm \operatorname{SEM}(n=6)$ of three independent experiments. The tests for significance were limited to ANOVA-Dunnet posttest, ${ }^{* *} P<0.001,{ }^{* * *} P<0.0001$ vs. control; ${ }^{+++} P<0.001 \mathrm{RKO}$ vs. SW613-B3 at $\mathrm{IC}_{50}$ dose. (c) Cells were exposed to the extract for 48. (h) Percentage of cells in the $G_{1}, S$, and $G_{2} / \mathrm{M}$-phases of the cell cycle was analyzed using a Facscanto II flow cytometer. Data were acquired and analyzed using DIVA software (Becton Dickinson). Data represented the mean \pm SEM $(n=6)$ of three independent experiments. The tests for significance were limited to ANOVA-Dunnet posttest, ${ }^{* * *} P<0.0001$ for $G_{1}, S$, and $G_{2} / \mathrm{M}$.

signals corresponding to the carbohydrate, analyzed together with the proton spectra, indicated that it was the $\beta$-Dglucopiranoside. All the data obtained by NMR were ascribable to a derivative of ellagic acid. The comparison of physical and spectroscopic data [35] indicated that the isolated compound 2 was $3^{\prime}$-O-methyl ellagic acid $4-O-\beta$-D- 

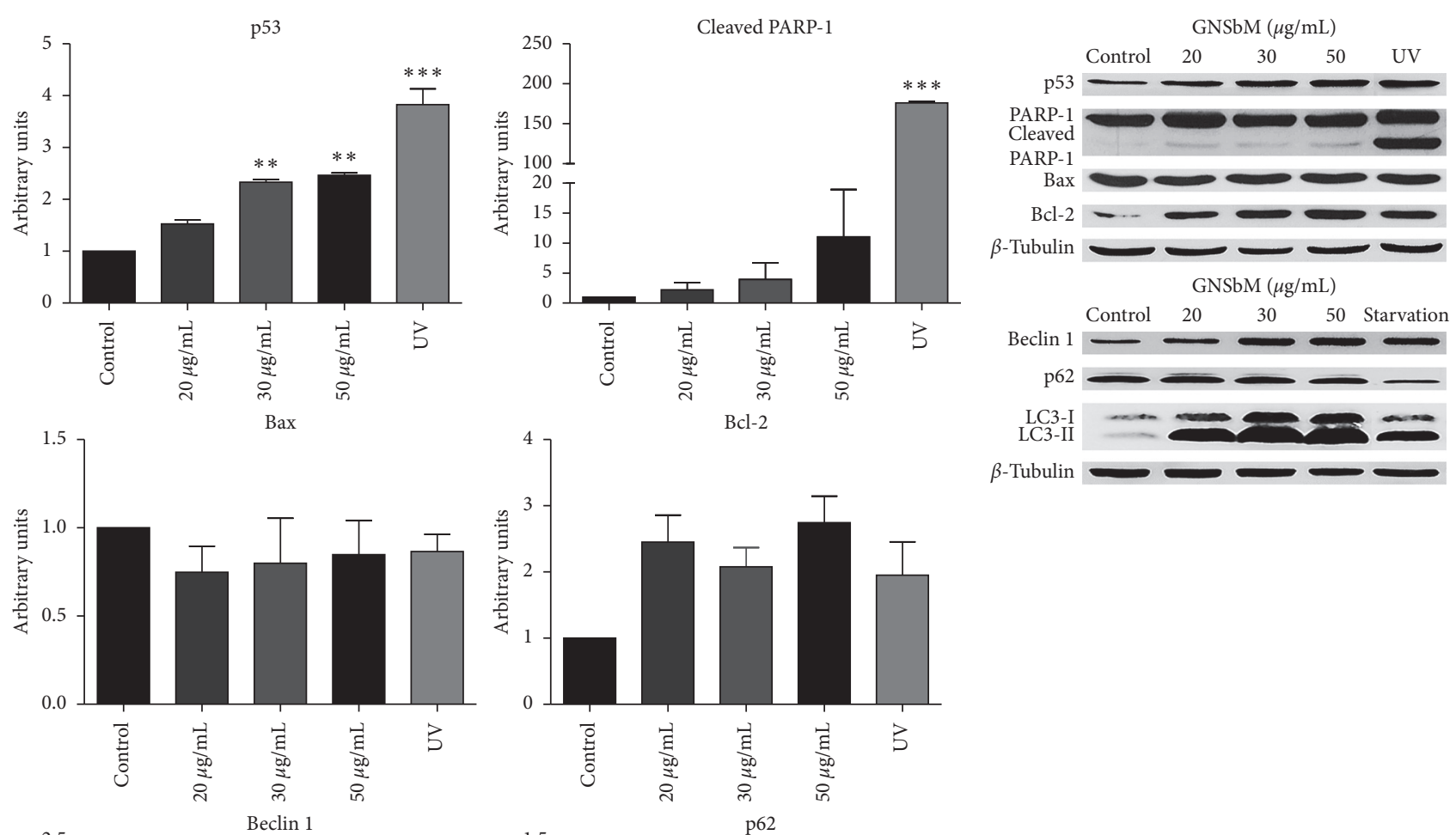

$\beta$-Tubulin
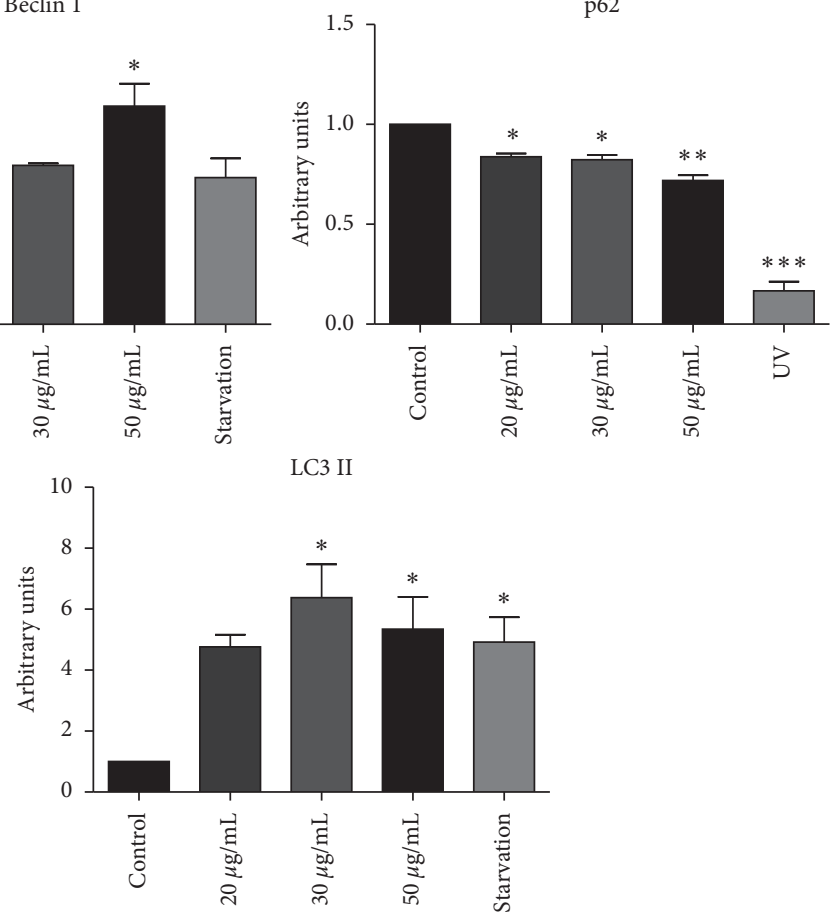

(a)

(b)

FIGURE 2: GNSbM extract induces autophagy on RKO line cell. Cells were exposed to GNSbM or UV radiation or starvation in PBS. Total protein was separated in a SDS-PAGE followed by Western blot analysis with indicated antibodies against p53, apoptotic and autophagy biomarkers, and tubulin as a loading control. (a) Quantification of the level of p53 expression and the apoptotic and autophagy biomarkers. Data represented the mean $\pm \operatorname{SEM}(n=6)$ of three independent experiments. The tests for significance were limited to ANOVA-Dunnet posttest: ${ }^{*} P<0.01,{ }^{* *} P<0.001$, ${ }^{* * *} P<0.0001$ vs. control. (b) Western blot pictures demonstrating the effect observed in RKO cell line. Although p53 showed to be overexpressed in a dose-dependent manner, no apoptotic activity was detected, and autophagy activity was monitored after treatment.

glucopyranoside. Compound 3 was a white amorphous powder. The NMR spectra were taken in deuterated DMSO, submitted to analyses. The ${ }^{1} \mathrm{H}$ NMR showed the resonances of five quaternary methyl groups at $0.52,0.54,0.94,1.08$, and $1.26 \mathrm{ppm}$, together with a methyl doublet at $\delta 0.86$. An olefinic proton in $5.14 \mathrm{ppm}$ suggested an ursane-type 

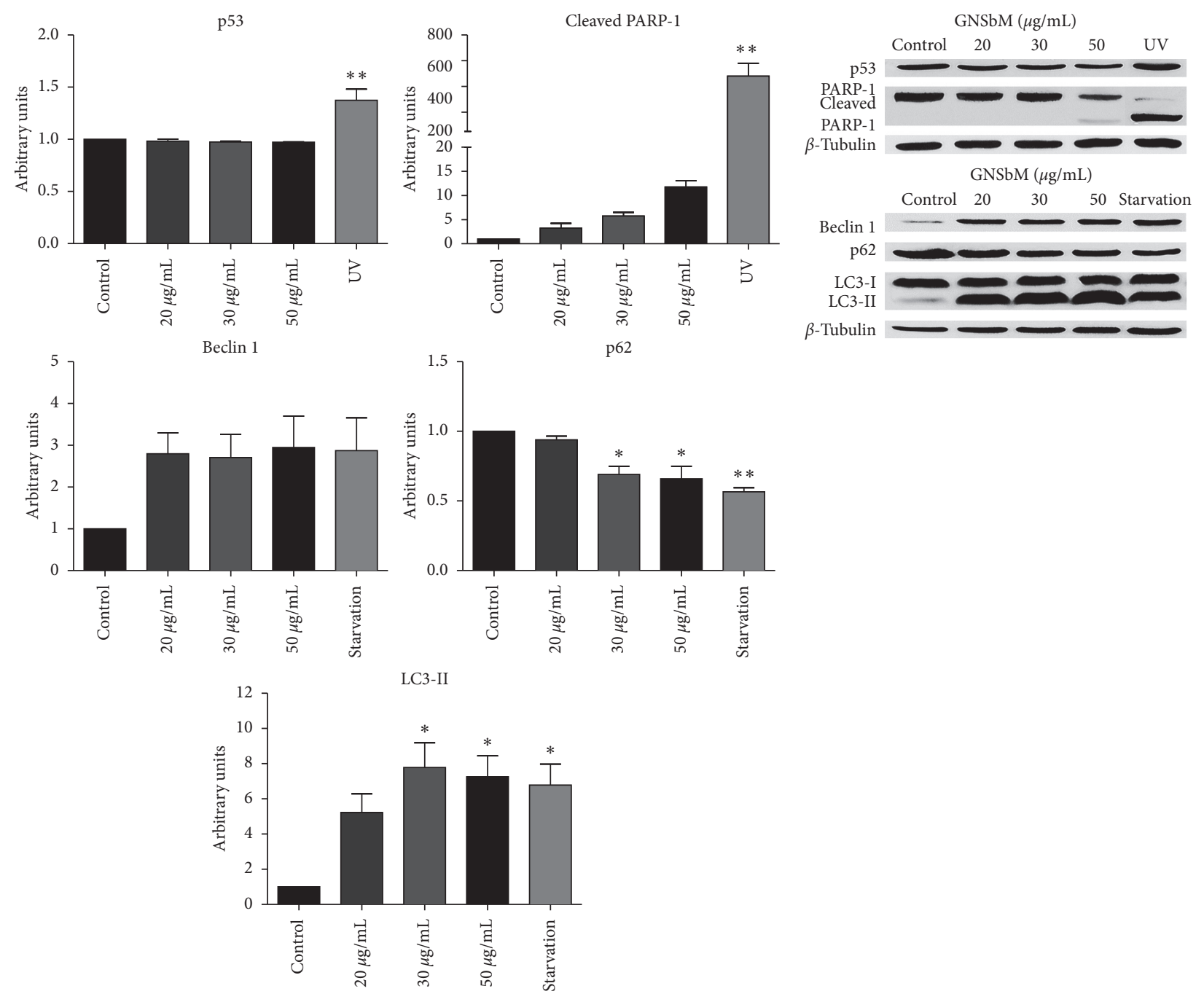

(a)

(b)

FIGURE 3: GNSbM extract induces autophagy on SW613-B3 cell line. Cells were exposed to GNSbM or UV radiation or starvation in PBS. Total protein was separated in a SDS-PAGE followed by Western blot analysis with indicated antibodies against p53, apoptotic and autophagy biomarkers, and tubulin as a loading control. (a) Quantification of the level of p53 expression and the apoptotic and autophagy biomarkers. Data represented the mean \pm SEM $(n=6)$ of three independent experiments. The tests for significance were limited to the ANOVA-Dunnet posttest: ${ }^{*} P<0.01,{ }^{* *} P<0.001,{ }^{* * *} P<0.0001$ vs. control. (b) Western blot pictures demonstrating the effect observed in Sw613-B3 cell line. No p53 expression was observed as expected although autophagy activity was detected after treatment.

triterpene for the aglycone of this glycosylated compound. Few multiplets between 3.8 and $4.60 \mathrm{ppm}$ were ascribable to a sugar moiety. The carbon NMR spectra analyzed with the help of DEPT experiment revealed for the aglycone triterpene 30 carbons, including six methyl groups, nine methylene groups, counting one oxygenated, seven methine groups with two oxygenated at 77.7 and $67.7 \mathrm{ppm}$, and one olefinic group at $138.4 \mathrm{ppm}$; eight quaternary carbons comprising the olefinic at $127.2 \mathrm{ppm}$, one oxygenated at $72.4 \mathrm{ppm}$, and the carboxyl ester group at $175.8 \mathrm{ppm}$. Comparative study of the resonances of the sugar indicated that it was the $\beta$-D-glucoside. The $2 \mathrm{D}$ experiments, COSY, HMQC, and HMBC were in agreement with the proposed structure. All the data were compared with the literature
$[36,37]$ to finally consider this compound as 19-hydroxyasiatic acid monoglucoside.

Regarding this, lupeol (1), 3'-O-methyl ellagic acid 4-O$\beta$-D-rhamnopyranoside (2), and asiatic acid- $\beta$-D-glucoside (3) are reported here for the first time in this genus. For instance, lupeol has been widely reported for its anticancer effect against various cancer cells, such as oral cancer, pancreatic cancer, gallbladder cancer, prostate cancer, and colorectal cancer. [38-41] Also, asiatic acid is known to be cytotoxic to several tumor cell lines. However, asiatic acid-induced cell death was mainly apoptotic, demonstrated in colon cancer RKO cells $[42,43]$. Hence, the presence of these phytochemicals in GNSbM might be synergistically responsible for the autophagy-inducing effect, as suggested by our results. 

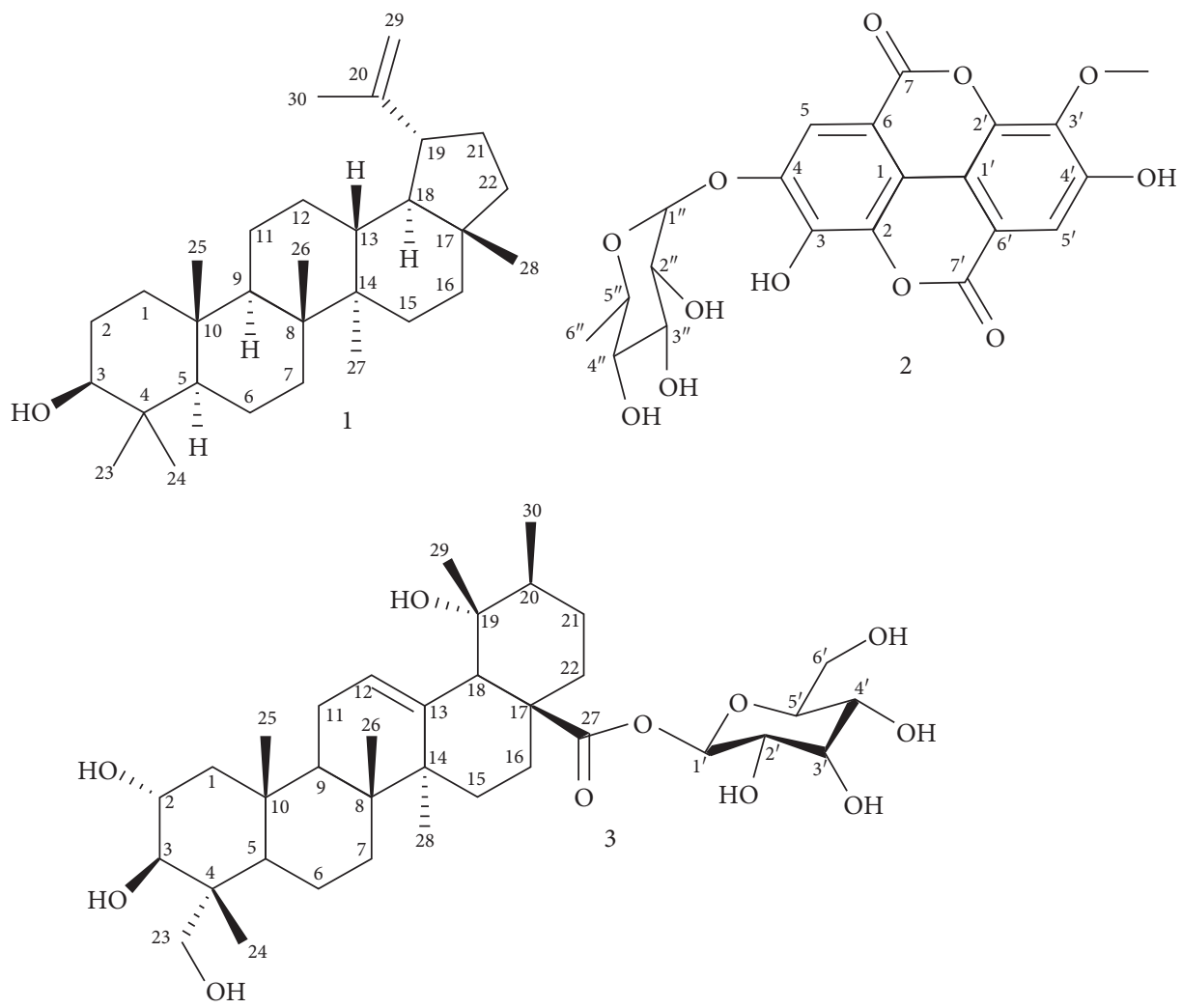

FIgURE 4: Structures of compounds isolated from methanolic extract from the stem bark of G. neuberthii (GNSbM).

\section{Conclusions}

In summary, different extracts of $G$. neuberthii were evaluated; the one with the greatest cytotoxic effect was the socalled GNSbM, which considerably reduced cell viability in both RKO cell line, with wt p53, and SW613-B3, with mutated p53, in a dose-dependent manner after $48 \mathrm{~h}$ of exposure. In addition, activation of the apoptotic route was discarded and the evidence of autophagic activity was detected. Finally, three compounds were identified in this extract: lupeol, $3^{\prime}$-O-methyl ellagic acid $4-\mathrm{O}-\beta$-D-rhamnopyranoside, and asiatic acid- $\beta$-D-glucoside, which have been shown to have antitumor effects.

\section{Data Availability}

The datasets generated and/or analyzed during the current study are available from the corresponding author on reasonable request.

\section{Conflicts of Interest}

The authors declare that there are no conflicts of interest regarding the publication of this paper.

\section{Authors' Contributions}

Luis M. Guamán-Ortiz and Juan C. Romero-Benavides contributed equally to this work.

\section{Acknowledgments}

This work was supported by International Centre for Genetic Engineering and Biotechnology (ICGEB), Trieste, Italy (ECU1601 EC) and Universidad Técnica Particular de Loja (UTPL), Loja, Ecuador (PROY_CCSAL_1266). The authors want to thank Dr. A. Ivana Scovassi for her support in the observations and analysis of experimental results and reviewing the English version.

\section{Supplementary Materials}

Different parts of the G. neubetthii were macerated for $72 \mathrm{~h}$ in a light-free environment with three dissolvents separately: hexano, ethyl acetate, and methanol. The extracts were concentrated at $50 \mathrm{mbar}$ and $37^{\circ} \mathrm{C}$ on a rotary evaporator. The appearance and weight of the extracts were recorded, and the yield was calculated. (Supplementary Materials)

\section{References}

[1] F. Bray, J. Ferlay, I. Soerjomataram et al., "Global cancer statistics 2018: GLOBOCAN estimates of incidence and mortality worldwide for 36 cancers in 185 countries," $C A$ : $A$ Cancer Journal for Clinicians, vol. 68, no. 6, pp. 394-424, 2018.

[2] M. S. Sierra and D. Forman, "Cancer in central and South America: methodology," Cancer Epidemiology, vol. 44, pp. S11-S81, 2016. 
[3] M. C. Maiuri and G. Kroemer, "Therapeutic modulation of autophagy: which disease comes first?" Cell Death \& Differentiation, vol. 26, no. 4, pp. 680-689, 2019.

[4] A. L. Harvey, R. Edrada-Ebel, and R. J. Quinn, "The reemergence of natural products for drug discovery in the genomics era," Nature Reviews Drug Discovery, vol. 14, no. 2, pp. 111-129, 2015.

[5] L. N. Joppa, P. Visconti, C. N. Jenkins, and S. L. Pimm, "Achieving the convention on biological diversity's goals for plant conservation," Science, vol. 341, no. 6150, pp. 1100-1103, 2013.

[6] R. V. A. SALTOS, T. E. R. Vásquez, J. A. LAZO et al., "The use of medicinal plants by rural populations of the Pastaza province in the Ecuadorian Amazon," Acta Amazonica, vol. 46, no. 4, pp. 355-366, 2016.

[7] P. Vásquez-Ocmín, S. Cojean, E. Rengifo et al., "Antiprotozoal activity of medicinal plants used by Iquitos-Nauta road communities in Loreto (Peru)," Journal of Ethnopharmacology, vol. 210, pp. 372-385, 2018.

[8] S. C. Mandal, V. Mandal, and A. K. Das, "Preface," in Essentials of Botanical Extraction, S. C. Mandal, V. Mandal, and A. K. Das, Eds., Academic Press, Boston, MA, USA, pp. 173-185, 2015.

[9] A. K. Jamal, W. A. Yaacob, and L. B. Din, "A chemical study on Phyllanthus reticulatus," Journal of Physical Science, vol. 19, pp. 45-50, 2008.

[10] N. Bailón-Moscoso, J. C. Romero-Benavides, M. Sordo et al., "Phytochemical study and evaluation of cytotoxic and genotoxic properties of extracts from Clusia latipes leaves," Revista Brasileira de Farmacognosia, vol. 26, no. 1, pp. 44-49, 2016.

[11] J. C. Romero-Benavides, N. Bailon-Moscoso, H. Parra-Delgado et al., "Argentatin B derivatives induce cell cycle arrest and DNA damage in human colon cancer cells through p73/ p53 regulation," Medicinal Chemistry Research, vol. 27, no. 3, pp. 834-843, 2018.

[12] L. M. Guamán Ortiz, A. L. Croce, F. Aredia et al., "Effect of new berberine derivatives on colon cancer cells," Acta Biochimica et Biophysica Sinica, vol. 47, no. 10, pp. 824-833, 2015.

[13] C.-H. Lee, S.-B. Wu, C.-H. Hong, H.-S. Yu, and Y.-H. Wei, "Molecular mechanisms of UV-induced apoptosis and its effects on skin residential cells: the implication in UV-based phototherapy," International Journal of Molecular Sciences, vol. 14, no. 3, pp. 6414-6435, 2013.

[14] Y. Stroikin, U. Johansson, S. Asplund, and K. Öllinger, "Increased resistance of lipofuscin-loaded prematurely senescent fibroblasts to starvation-induced programmed cell death," Biogerontology, vol. 8, no. 1, pp. 43-53, 2007.

[15] N. Bailon-Moscoso, G. González-Arévalo, G. Velásquez-Rojas et al., PLoS One, vol. 10, Article ID e0136527, 2015.

[16] C. Jiang, L. Jiang, Q. Li et al., "Pyrroloquinoline quinine ameliorates doxorubicin-induced autophagy-dependent apoptosis via lysosomal-mitochondrial axis in vascular endothelial cells," Toxicology, vol. 425, Article ID 152238, 2019.

[17] Y. Frión-Herrera, D. Gabbia, A. Díaz-García, O. CuestaRubio, and M. Carrara, "Chemosensitizing activity of Cuban propolis and nemorosone in doxorubicin resistant human colon carcinoma cells," Fitoterapia, vol. 136, p. 104173, 2019.

[18] J. Wang, C. Hu, J. Wang et al., "Checkpoint blockade in combination with doxorubicin augments tumor cell apoptosis in osteosarcoma," Journal for ImmunoTherapy, vol. 42, no. 9, pp. 321-330, 2019.
[19] D. Menendez, A. Inga, and M. A. Resnick, "The expanding universe of p53 targets," Nature Reviews Cancer, vol. 9, no. 10, pp. 724-737, 2009.

[20] F. Toledo and G. M. Wahl, "Regulating the p53 pathway: in vitro hypotheses, in vivo veritas," Nature Reviews Cancer, vol. 6, no. 12, pp. 909-923, 2006.

[21] M. M. Hippert, P. S. O’Toole, and A. Thorburn, “Autophagy in cancer: good, bad, or both?: figure 1," Cancer Research, vol. 66, no. 19, pp. 9349-9351, 2006.

[22] L. Galluzzi, I. Vitale, S. A. Aaronson et al., "Oncogene-induced senescence and tumour control in complex biological systems," Cell Death \& Differentiation, vol. 25, pp. 486-541, 2018.

[23] G. Chaitanya, J. S. Alexander, and P. Babu, "PARP-1 cleavage fragments: signatures of cell-death proteases in neurodegeneration," Cell Communication and Signaling, vol. 8, no. 1, p. 31, 2010.

[24] L. M. Luis, M. Guaman-Ortiz, V. Vincenzo Giansanti, F. Francesca Dona, and A. A. Ivana Scovassi, "Pharmacological effects of PARP inhibitors on cancer and other diseases," Current Enzyme Inhibition, vol. 7, no. 4, pp. 244-258, 2012.

[25] J. Lv and Y. Xing, "Effects of UV on apoptotic factors in lens epithelial cells of an animal model," Experimental and Therapeutic Medicine, vol. 16, pp. 2309-2312, 2018.

[26] L. Poillet-Perez and E. White, "Role of tumor and host autophagy in cancer metabolism," Genes \& Development, vol. 33, no. 11-12, pp. 610-619, 2019.

[27] F. Aredia, L. M. Guamán Ortiz, V. Giansanti, and A. I. Scovassi, "Autophagy and cancer," Cells, vol. 1, no. 3, pp. 520-534, 2012.

[28] J. Kubisch, D. Türei, L. Földvári-Nagy et al., "Complex regulation of autophagy in cancer - integrated approaches to discover the networks that hold a double-edged sword," Seminars in Cancer Biology, vol. 23, no. 4, pp. 252-261, 2013.

[29] X. Lv, K. Wang, W. Tang et al., "miR-34a-5p was involved in chronic intermittent hypoxia-induced autophagy of human coronary artery endothelial cells via $\mathrm{Bcl}-2 /$ beclin 1 signal transduction pathway," Journal of Cellular Biochemistry, vol. 120, no. 11, pp. 18871-18882, 2019.

[30] J. Doherty and E. H. Baehrecke, "Life, death and autophagy," Nature Cell Biology, vol. 20, no. 10, pp. 1110-1117, 2018.

[31] R. Kang, H. J. Zeh, M. T. Lotze, and D. Tang, "The Beclin 1 network regulates autophagy and apoptosis," Cell Death \& Differentiation, vol. 18, no. 4, pp. 571-580, 2011.

[32] T. E. Rusten and H. Stenmark, "p62, an autophagy hero or culprit?” Nature Cell Biology, vol. 12, no. 3, pp. 207-209, 2010.

[33] R. Gómez-Sánchez, S. M. S. Yakhine-Diop, M. RodríguezArribas et al., "mRNA and protein dataset of autophagy markers (LC3 and p62) in several cell lines," Data in Brief, vol. 7, pp. 641-647, 2016.

[34] L. Guaman-Ortiz, M. Orellana, and E. Ratovitski, "Natural compounds as modulators of non-apoptotic cell death in cancer cells," Current Genomics, vol. 18, no. 2, pp. 132-155, 2017.

[35] X.-H. Yan and Y.-W. Guo, "Two new ellagic acid glycosides from leaves of diplopanax stachyanthus," Journal of Asian Natural Products Research, vol. 6, no. 4, pp. 271-276, 2004.

[36] D.-L. Cheng and X.-P. Cao, "Pomolic acid derivatives from the root of Sanguisorba officinalis," Phytochemistry, vol. 31, no. 4, pp. 1317-1320, 1992.

[37] O. T. Kim, M. L. Jin, D. Y. Lee, and R. Jetter, "Characterization of the Asiatic Acid Glucosyltransferase, UGT73AH1, Involved in Asiaticoside Biosynthesis in Centella asiatica (L.) Urban," 
International Journal of Molecular Sciences, vol. 18, pp. 1-11, 2017.

[38] H. H. Kwon, J. Y. Yoon, S. Y. Park et al., “Activity-guided purification identifies lupeol, a pentacyclic triterpene, as a therapeutic agent multiple pathogenic factors of acne," Journal of Investigative Dermatology, vol. 135, no. 6, pp. 1491-1500, 2015.

[39] T. K. Lee, R. T. P. Poon, J. Y. Wo et al., "Lupeol suppresses cisplatin-induced nuclear factor- B activation in head and neck squamous cell carcinoma and inhibits local invasion and nodal metastasis in an orthotopic nude mouse model," Cancer Research, vol. 67, no. 18, pp. 8800-8809, 2007.

[40] H. R. Siddique and M. Saleem, "Beneficial health effects of lupeol triterpene: A review of preclinical studies," Life Sciences, vol. 88, pp. 302-306, 2011.

[41] M. Saleem, "Lupeol, a novel anti-inflammatory and anticancer dietary triterpene," Cancer Letters, vol. 285, no. 2, pp. 109-115, 2009.

[42] C. W. Cho, D. S. Choi, M. H. Cardone, C. W. Kim, A. J. Sinskey, and C. Rha, "Glioblastoma cell death induced by asiatic acid," Cell Biology and Toxicology, vol. 22, no. 6, pp. 393-408, 2006.

[43] M. F. N. Meeran, S. N. Goyal, K. Suchal, C. Sharma, C. R. Patil, and S. K. Ojha, "Pharmacological Properties, Molecular Mechanisms, and Pharmaceutical Development of Asiatic Acid: A Pentacyclic Triterpenoid of Therapeutic Promise," Frontiers in Pharmacology, vol. 9, 2018. 